Preprints of the

Max Planck Institute for

Research on Collective Goods

Bonn 2014/9

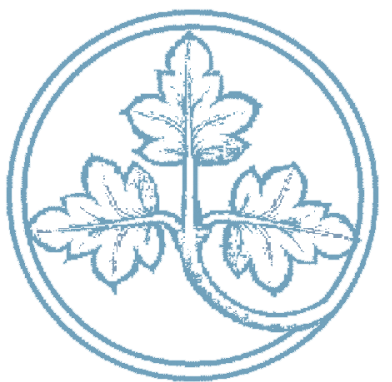

Financial Stability, Monetary Policy, Banking Supervision, and Central Banking

Martin Hellwig

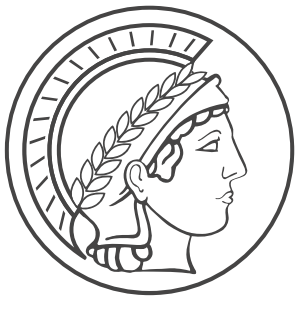




\section{Financial Stability, Monetary Policy, Banking Supervision, and Central Banking}

Martin Hellwig

July 2014 


\title{
Financial Stability, Monetary Policy, Banking Supervision, and Central Banking ${ }^{1}$
}

\author{
Martin F. Hellwig
}

\begin{abstract}
The paper gives an overview over issues concerning the role of financial stability in monetary policy and the relation between banking supervision and central banking. Following a brief account of developments in the European Monetary Union since its creation, the systematic treatment contains four parts, first a systematic discussion of how a central bank's operations differ from those of an administrative authority; second, a discussion of how the shift from convertible currencies to paper currencies has affected our understanding of monetary policy and the role of financial stability; third, a discussion of moral hazard in banking and banking supervision as a threat to monetary dominance and to the effective independence of central bank decision making in an environment in which financial stability is an essential precondition for reaching the central bank's macroeconomic objective, e.g. price stability; finally, a discussion of the challenges for institution design and policy, with special attention to developments in the euro area.
\end{abstract}

Key Words: Financial stability, monetary policy, banking supervision, central banking, bank resolution, independence of central banks and supervisory authorities

JEL Classifications: E42, E44, E51, E52, E58, G18, G28, G33, H63

1 Paper presented at the First ECB Forum, Sintra, May 25, 2014. I am grateful for very helpful comments from Stephen Cecchetti, Christoph Engel, Stephan Luck, Niels Petersen, and Martin Summer. 


\section{Financial Stability and Monetary Policy in the Euro Area: Where Do We Come From?}

Sometime in 1997, when I was on the conseil d'administration of the research foundation of the Banque de France, I suggested that it might be interesting to promote research on the problems that monetary union would pose for the relation between central banking, which would be supranational, and banking supervision, which would remain national under the home country principle. ${ }^{2}$ This proposal was turned down on the grounds that banking supervision and central banking have nothing to do with each other: Central banking and monetary policy are concerned with price stability, banking supervision is concerned with the safety and soundness of banks. Any notion that central banking has to do with financial stability would generate moral hazard. When I pointed to the fact that, in 1990, Mr. Greenspan had found it appropriate to turn monetary policy around in order to avoid a major crisis of US commercial banks, I received the answer that this measure had not harmed price stability. ${ }^{3}$

On that occasion, and many subsequent ones, I thought that treating the relation between central banking and banking supervision as a non-issue was a way to preempt or defuse any attempts by supranational institutions to challenge the national prerogative in banking. I also thought that this objective could be seen behind the promotion of bank mergers, even megamergers, at the national level. ${ }^{4}$

However, the underlying thinking has been more widespread. The Maastricht Treaty names price stability as the objective of monetary policy and does not say a word about financial stability. In academia, before the crisis, and with some authors even today, there was a view that inflation rates, inflation expectations, and the implied relative intertemporal prices were all that mattered, and no words or modelling efforts were devoted to the role of financial institutions in the monetary system. ${ }^{5}$

For a long time, this thinking was also reflected in the ECB's policy stance, which was based on using interest rate policy to deal with price stability concerns and using unorthodox measures to deal with financial stability concerns. If one believes that these issues can really be compartmentalized, this may seem like a clear-cut assignment of different instruments to different policy objectives.

However, one must doubt whether the compartmentalization of issues works as neatly in the real world as in the theory. Whereas inflation fears motivated the ECB to raise interest rates in

$2 \quad$ For a detailed account of my concerns, see Hellwig (2007).

3 On the 1990 crisis, see Bernanke and Lown (1990), Boyd and Gertler (1994).

4 For example, the merger of BNP and Banque Paribas in 2000 was strongly supported by political and regulatory authorities. At the time, the President of the Banque de France suggested that it would be even better if Société Générale were to join in the merger as well. In Germany, in 2004, the Federal Chancellor called for the industry to get their act together and form a "national champion". For a discussion of the risks of such a policy, see Monopolkommission (2004), items 30, 31, and Bundesregierung (2005), items $23-25$.

5 See, for example, Bernanke and Gertler (2001), Svensson (1999), Woodford (2003). For a critique, see White (2007). 
mid-2008, and again in mid- 2011, the effects of these interest rates on banks' funding costs may well have contributed to a worsening of the financial crisis, in 2011 as well as 2008.

The crisis of 2011 worked as a catalyst for change. In the summer and fall of that year, worries about the implications of the Greek haircut for bank solvency caused the market funding of European banks to erode. As banks were selling assets to get cash, asset prices declined. This price decline imposed further losses on banks, and confidence in the banks eroded even further. The decision of the EU Summit of October to impose stricter equity requirements in order to allay the prevailing solvency concerns was initially followed by further deleveraging and further asset price declines. The downward spiral was only stopped when the ECB stepped in with its Long-Term Refinancing Operation (LTRO), which provided financial institutions - and markets - with an assurance of reliable and cheap bank funding over a substantial period of time. In contrast to the previous compartmentalization of objectives and instruments, the LTRO involved a use of low interest rates for a financial stability objective.

As a means of stopping the crisis of 2011, the LTRO was very successful. Even so, it has been controversial. Less controversial perhaps than the Securities Markets Program (SMP) in 2010 and 2011 or the announcement of Outright Monetary Transactions (OMT) in 2012, but the difference has more to do with legal differences than with the policies themselves. Whereas people who object to the ECB's overall policy stance, or even to the ECB's existence, like to attack SMP and OMT on the grounds that they violate the Treaty's prohibition of ECB funding of member state governments, there is no doubt that the LTRO is fully covered by the Treaty. However, I have read many statements from academics, journalists, and even the Deutsche Bundesbank, saying that the dramatic increase in the quantity of high-powered money and the low interest rates that are associated with the LTRO, as well as other policies of the ECB, carry a risk of high future inflation. If this risk has not yet materialized, the reason might be that, as we know from the writings of Milton Friedman, lags in monetary policy are long and variable. ${ }^{6}$

By now, in May 2014, we are of course worrying about deflation rather than inflation. The objections may therefore seem pointless. They still raise the question of what is the relation of price stability and financial stability. To what extent is there a tradeoff and what conceptual framework should we use to think about such a tradeoff? Is there a need to change the legal norm so as to encompass an objective of financial stability? Or should we take it for granted that the present formulation already encompasses some key elements of financial stability as part of the requirement that the European System of Central Banks (ESCB) should "define and implement monetary policy” (Art. 127 (2) TFEU)?

And then there is the issue of moral hazard. In the discussion that I mentioned in the introductory paragraph, I had emphasized the success of the 1990 turnaround of US monetary policy in preventing a major banking crisis. By lowering short-term interest rates, the Federal Re- 
serve provided commercial banks with the means to rebuild their equity by playing the yield curve, earning record profits one quarter after another for close to four years. However, as they were betting on the Federal Reserve's low-interest rate policy, financial institutions took very risky positions, which is one reason why the very moderate policy turnaround in 1994 caused substantial turmoil in the US financial system. More generally, we have come to understand that the so-called "Greenspan put”, an anticipation that the Federal Reserve would neutralize any adversary developments in the financial sector, contributed to the excessive risk taking of many financial institutions in the years before 2007.

The LTRO benefited not only healthy banks but also banks whose health was dubious, perhaps even banks that would have been insolvent if they had been forced to uncover their hidden losses. In fact, the availability of ECB support has been most important for those banks that had the weakest equity positions and the greatest difficulties in obtaining market funding. For these banks, borrowing from the ECB at one percent or less and lending to their own governments at four or five percent appears as a wonderful way to avoid default and rebuild equity. ${ }^{7}$

Policies that benefit banks which are actually insolvent violate the principle that solvency problems of banks should be dealt with by governments and central banks should only deal with liquidity problems. In the euro area, a decade ago, the various Memoranda of Understanding (MoU) for how to deal with banks in difficulties provided for a division of tasks according to this principle, with the added provision that liquidity problems of individual institutions should be dealt with by the national central banks, and liquidity problems of the entire system by the ECB. ${ }^{8}$ To the extent that de facto insolvent banks benefit from ECB funding, these principles are violated. However, if banking supervision is in the hands of national authorities and these authorities exercise forbearance towards the solvency problems of "their" banks, there is little the ECB can do about it.

The very determination to preserve financial stability as an important element of monetary stability puts the ECB into a position of weakness. Given the knowledge that the ECB will support the system anyway, the pressure on national governments and national supervisors to clean up their banking systems is that much weaker. Some politicians may in fact understand that the very weakness of their banks gives them an indirect access to the printing press. After all, with the LTRO, a large part of the money that banks got from the ECB was lent to the banks' own governments. ${ }^{9}$

Fear of such moral hazard, on the side of banks and on the side of national governments and national supervisors, seems to have played an important role in the move towards banking union. To be sure, the 2012 decision to create a Single Supervisory Mechanism (SSM) was triggered by the Spanish request for funding by the European Stability Mechanism (ESM) to

$7 \quad$ According to Acharya and Steffen (2013), the banks that had the weakest equity positions were most active in this "greatest carry trade ever". Bundesbank (2012) and Sinn (2013) are very critical of this feature of ECB lending to private banks.

8 For a detailed critical discussion of these MoUs, see Hellwig (2007).

$9 \quad$ Acharya and Steffen (2013). 
recapitalize Spanish banks and was intended to reduce the moral hazard that ESM involvement might create. However, this move was also strongly supported by the ECB, presumably because it had wanted to get out of a situation where monetary policy was persistently put under pressure by the weakness of financial institutions, a weakness that national governments and national supervisors could not or would not resolve. There is a danger of course that, with banking union, the ECB will be drawn ever more deeply into responsibility for financial stability and that the straightjacket for monetary policy may become even tighter. ${ }^{10}$

Legal proceedings, before the German Constitutional Court and soon before the European Court of Justice, must also be seen in this context. These proceedings are not just concerned with the question whether OMT violates the prohibition of central bank funding of governments. At a deeper level, they are motivated by the recognition that monetary policy has strong distributive effects, which give rise to worries about governance and moral hazard. In the context of the OMT program, the distributive effects are particularly obvious because the program stipulates selective interventions. However, the issue is more general as we see distributive effects arising also from those cheap central-bank loans under the LTRO. From the perspective of constitutional law in a democracy, governance of decisions that have such distributive effects is a fundamental issue.

In the following, I will give an overview over the different issues that financial-stability concerns raise for monetary policy. I will not be able to settle them, but I hope to provide a comprehensive overview and perhaps a conceptual structure that makes it possible to appreciate what the tradeoffs are. Such a structure is important if one wants to avoid shooting from the hip with partial arguments and recommendations that may end up having unintended, costly, and destructive consequences.

\section{Remarks on Central Banking}

I begin with a few remarks on what a central bank actually is and how it differs from other institutions. Political, legal, and academic discussion about the issues sometimes suffers from a lack of attention to institutional and operational detail. To be clear about terminology, even when the central bank is in charge of banking supervision, I use the term "central banking" exclusively for the non-supervisory activities of the institution.

\subsection{Central Banks Are Banks}

In contrast to supervision, central banking is mostly a form of banking rather than an administrative activity. Whereas administrative authorities are setting, interpreting and applying statutory rules, most activities of central banks involve transactions on a quid-pro-quo basis, such

10 For a more detailed account of the issues involved in the creation of a European Banking Union, see Hellwig (2014 a). 
as taking deposits from banks, granting loans to banks, or buying and selling assets in open markets. Conditions for these transactions are set by the central bank but, with one exception, the counterparties participate voluntarily in these transactions and are not forced to do so by fiat of the central bank or the government. The exception to this rule is given by minimum reserve requirements that force banks to hold cash or deposits with the central bank. Setting minimum reserve requirements is an administrative act. At this point, however, at a level of 1 $\%$ for deposits with a maturity of less than two years and 0 for higher maturities, minimum reserve requirements are practically irrelevant in Europe.

The fact that a central bank is a bank has two important consequences: First, no matter how it operates, its operation generates windfalls for its counterparties and possibly further windfalls for the counterparties' counterparties. Second, no matter how the central bank operates, it is subject to risk from its activities.

\subsection{Windfalls to Counterparties and Moral Hazard from Expectations of Central-Bank Availability Are Unavoidable}

Given that transactions are voluntary, any counterparty will usually obtain a surplus from them. A private bank that borrows from the central bank and that invests the money elsewhere is likely to earn a margin. If the bank uses the money for loans, the bank's borrowers may benefit as well. Similarly, an investor who sells a security to the central bank is likely to put the proceeds to a use that he considers better than the security that he sells. If the central bank's intervention causes securities prices to rise, all holders of the securities benefit. If the price increases induce the securities' issuers to expand their supplies of securities, the issuers may also benefit.

Such distributive effects from the central bank's activities arise no matter how the central bank operates. They are not limited to cases where the central bank lends to de facto insolvent banks or governments. Nor are they limited to times of crisis.

The question of who will benefit from these distributive effects is therefore unavoidable. As a student, I learnt that open-market interventions involve government bonds, rather than private-issuer shares or bonds because open-market operations involving private-issuer shares or bonds would cause discrimination between issuers and thus distort private markets. Today, the same kind of concern is raised about the effects of selectivity of government bond purchases under OMT.

Selectivity is discriminatory but so is any form of open market intervention. The selectivity of OMT is controversial because it collides with the textbook principle that open-market interventions should be nondiscriminatory. As mentioned, this principle was used to justify why open-market interventions should focus on government securities at a time when open-market interventions in private-issuer securities were considered discriminatory and open-market interventions in government bonds were not. With OMT, we are talking about open-market in- 
terventions in government bonds that are discriminatory. The distributive effects are easy to pinpoint and highly political.

However, the textbook principle that open-market interventions should be nondiscriminatory is itself problematic. Even with a single central government, open-market operations in that government's bonds are discriminatory and can be a source of distortions. In the United States, over decades, the use of such open-market operations for the Federal Reserve's interest rate policy enabled the monetization of government debt even without an outright regime of fiscal dominance. ${ }^{11}$

If the central bank avoids open-market operations altogether and relies on lending to commercial banks, one can ask why it is lending to commercial banks and not, for example, to investment banks or to hedge funds. One can also ask how it selects the banks to which it lends. In the United States, for example, access to the Federal Reserve's discount window has provided commercial banks with a major competitive advantage over investment banks, an advantage that contributed significantly to the pressures on the investment banks, before the crisis and in the crisis. ${ }^{12}$

Moral hazard from central bank intervention and central bank availability, to which I referred in the introduction, is also unavoidable, likely to arise even under the best of circumstances. ${ }^{13}$ If the central bank develops a routine for how to do its business, through open-market purchases or through lending to financial institutions, the private and public counterparties to the central bank's business will form expectations about the future availability of transactions with the central bank and will form their own plans accordingly. They will do the same if they do business with a private partner on a regular basis. ${ }^{14}$ The problem of moral hazard from the availability of the central bank must be seen as a problem of degree rather than one of principle.

Therefore the real policy question is not how to avoid windfalls to counterparties, selectivity, but how to minimize the distortions from these side-effects of central-bank activity. This question concerns the choice of counterparties, the preconditions that counterparties must satisfy, and the choice of contracts and securities that the central bank engages in. These choices in turn must be seen in relation to the monetary policy problems that the central banks are

11 For an Overview, see Thornton (1984).

12 For a discussion of these developments, see Admati and Hellwig (2013), chapters 4 and 5, and the references cited there.

13 As discussed by Goodhart (1988), moral hazard on the side of commercial banks has always been a concern for central banks.

14 In this context, it is worth remembering the systemic effects of the breakdown of wholesale short-term funding markets in September 2008. Many banks had counted on the availability of such funding and were squeezed for liquidity when the implosion of US money market funds in the wake of the Lehman bankruptcy caused these markets to disappear. For a detailed account, see Admati and Hellwig (2013), chapter 5. Hellwig (2014b) names the disappearance of potential trading partners on whom market participants had counted as an important category of systemic risk. 
faced with. For example, the privileged position of banks may be justified by the central role that bank deposits and payments from and to deposits have in the monetary system. ${ }^{15}$

\subsection{Risks From Assets Held Are Unavoidable}

Turning to the risks of the central bank's activities, such risks have been the basis for criticizing interventions of central banks in the years since the crisis. One example would be the Federal Reserve’s buying “toxic” assets, such as mortgage-backed securities or collateralized debt obligations, as a way of freeing financial institutions from the burden of having such dubious assets on their books. Another example would be the ECB's and other central banks' loosening of quality standards for the collateral they accept when lending to banks. Because the returns that central banks earn depend on the prices they pay for the assets and the interest rates they charge on loans and these variables affect both the expected returns and the risks of the central banks' portfolios, it is not always possible to distinguish whether the critics are concerned about excessive risks or about excessively low mean returns. In any case, the potential that central banks might end up making substantial losses - or merely earning substantially less than they could - looms large in the discussion. ${ }^{16}$

However, central banks may end up making substantial losses on any assets they hold. This is just as true for the most traditional and conventional of central-bank assets, such as gold or foreign exchange, as well as for the new-fangled assets that figured prominently in the financial crisis. From 1980 to 2001, as the gold price fell from 885 US\$ per ounce to 253 US\$ per ounce, a central bank that held gold would have seen the value of its position cut by more than two thirds. And even if the central bank had held on to the gold until its peak of 1500 US\$, its return since 1980 would have been less than 2 percent per year, nothing like a market compensation for the risks that were involved. Similarly, foreign reserves cause the central bank to make losses if the currency devalues. As the Bundesbank knows from experience, such losses can be particularly large if the reserves have been acquired with a view to avoiding a revaluation but in the end the defense of the old exchange rate was unsuccessful. ${ }^{17}$

The asset portfolios of central banks are typically very different from those of private banks, ${ }^{18}$ but whatever risks the assets involve must be borne by the central bank and its owners just as a private bank and its owners bear the risks of the bank's asset portfolio. Perhaps therefore, the question of what risks are acceptable for a central bank to bear without parliamentary approval, which has figured prominently in the legal dispute about the OMT program, should be

15 In the case of selectivity OMT, an important question would be whether the deepening fragmentation of monetary and financial systems that we have seen since 2009 requires monetary policy to be targeted at different subsystems separately.

16 See, for example, Bundesbank (2012), Sinn (2013), Bundesverfassungsgericht (2014).

17 According to Holtfrerich (1998), in 1969, the Bundesbank experienced speculative capital flows on the order of DM 20 billion into Germany before and out of Germany after the revaluation; with a revaluation of the DM by $9.3 \%$, these flows imposed a loss of about DM 1.6 billion on the Bundesbank.

18 As discussed by Goodhart (1988), the difference reflects not only the different tasks of the two types of banks but also the realization that, in view of the central bank's funding advantage, there would be serious problems if the central bank was to compete with private banks in their proper domains. 
seen in parallel with the question of what risks are acceptable for a publicly-owned and stateguaranteed bank to bear without parliamentary approval. An example would be Westdeutsche Landesbank, whose costs to taxpayers on losses since 2005 amount to 18 billion euros, according to the finance minister in charge. ${ }^{19}$

\subsection{Central Bank Debt is Not Really Debt}

The central bank does of course differ from other banks because it ha sbeen given certain privileges by the government. ${ }^{20}$ The central bank has the exclusive right to issue money, and the money that it issues serves as legal tender. ${ }^{21}$

In a previous era, bank notes were debt instruments that entitled the bearer to receive specified amounts of gold whenever he wishes. Relying on such debt for funding was attractive because, for as long as the notes were in circulation, the issuer could put the funds that he had obtained to some other use. By giving the central bank a monopoly, the government made sure that profits would not be eroded by competition. ${ }^{22}$ By making bank notes legal tender, it enhanced the central bank’s profitability even more.

Even with a monopoly on note issuance, as long as these notes involve a substantive legal obligation, a central bank faces constraints that are similar to the ones faced by private banks: It must manage its activities and its assets so that it can always fulfil the obligations implied by its debt. If bank notes promised their bearers payments in gold, this meant that the central bank must manage its gold reserves appropriately. ${ }^{23}$ Even if bank notes are not convertible into gold, the same kinds of concerns arise if the central bank is committed to maintain a fixed exchange rate with some other currency.

However, since the abandonment of the Bretton-Woods system of fixed exchange rates, central banks are no longer subject to such constraints. The notes they issue are no longer debt in

19 See "WestLB kostet Steuerzahler 18 Milliarden Euro" (West LB costs taxpayers €18 billion), , Handelsblatt, June 20, 2012 In this context, it is of interest to observe that, in the Land of NordrheinWestfalen, the owner of Westdeutsche Landesbank, a parliamentary request for information about the government's involvement in the bank's disastrous investment decision was turned down on the grounds that this information was a "business secret". The German Constitutional Court itself used a similar argument to turn down a request from the federal parliamentary party Die Linke to obtain information (and parliamentary control) concerning massive real-estate sales by Deutsche Bahn AG, the governmentowned railway company; see Bundesverfassungsgericht (2011).

20 Unless the distinction is important, I use the term „government“ as referring to both, legislative and executive branches of government.

21 The importance of money being legal tender is stressed by Goodhart (1998). For a critical assessment, see Hayek (1977).

22 In England before Peel's Bank Act, bank notes were issued by other banks as well as the Bank of England. In other countries, such as the United States or Switzerland, the creation of the central bank replaced a system of competing bank note issuance by private banks. See Admati and Hellwig (2013), chapter 10, and the references given there, as well as Baltensperger (2012).

23 Goodhart (1988) observes that the conflict between this business need and whatever other objectives central banks were trying to fulfil has been a constant theme in the history of central banking. Eichengreen (1992) explains how the concern for convertibility damaged the ability of central banks to deal with the problem of the Great Depression. He also points out that, with some central banks, this kind of thinking persisted long after the regime change that would have allowed a change of policy stance. 
any meaningful sense of the word. The issue of bank notes does not oblige the central bank to do anything. And the deposit that a private bank might have with the central bank obliges the central bank to give the corresponding amount in notes on demand to the private bank; this is an obligation that the central bank can always fulfil.

Balance sheets of central banks show the central bank's issue of notes and deposits as a liability. However, this is an anachronism, a bookkeeping convention, which hides the fact that the central bank's note issue does not involve any obligation to the acquirers of the notes. If a central bank issues notes or deposits and acquires assets, and if the central bank makes a loss on those assets, there still is no risk that it might default. By the conventional criterion of comparing the value of assets to the value of outstanding debt, a central bank might be deemed to be insolvent but, in contrast to private banks or non-financial firms, this has no practical consequences. The reason is that the central bank's note issue does not oblige it to do anything and the obligations on deposits can always be fulfilled by issuing notes.

There is an exception that proves the rule. If a central bank borrows foreign currency from another central bank or from private parties, for example in order to support its own banks if they have borrowed in that currency, then there is a genuine risk of default. Under a swap agreement, in 2011, the ECB borrowed dollars from the Federal Reserve in order to support European banks whose dollar funding from money market funds had vanished. If events had taken an even worse turn than they did, at some point, the question might have arisen whether the ECB would be able to repay the Federal Reserve. After all, the ECB cannot create dollars, only euros.

For obligations that are denominated in euros however, there is no risk of default of the central bank. Nor is there necessarily a risk that losses on assets might impose an obligation on taxpayers; such a risk only arises if the central bank is required to have a minimum amount of equity and if equity is calculated in terms of traditional balance sheet conventions, which treat the central bank's note issue as debt even though it imposes no obligation on the central bank. $^{24}$

Going beyond legal issues, losses on assets may harm the central bank's credibility and thereby its ability to achieve its policy objectives. If the central bank were to report substantial losses, economic actors might expect it to try to make up for them in some way or other. One way to do so might be to expand its issue of money and invest in assets that earn a positive return. This would be profitable but might also be inflationary. If the central bank wants to maintain the credibility of its anti-inflationary stance, it is therefore well-advised to control the risks that it runs. However, this is a matter of policy judgment rather than legal obligation.

24 The link between potential losses on assets and potential demands on taxpayers is thus much less direct than the German Constitutional Court has surmised in Bundesverfassungsgericht (2014). It is also much less direct than in the case of the Landesbanken, which have benefited from explicit and unlimited state guarantees of their liabilities, which are indeed legal obligations.. 


\subsection{Fiscal Implications of Central Banking Are Unavoidable}

Even though the central bank cannot go bankrupt, risks from the central bank's assets can affect taxpayers. Any profits that the central bank earns and distributes go to its owners. For the owners, therefore, any risks in the central bank's investment policy involve a risk to future profit distributions.

As central banks today are mainly owned by governments, this means that profit distributions from central banks go into the governments' budgets. ${ }^{25}$ If the central bank makes losses on its assets and if, therefore, its profit distribution to the government is reduced, the government must either reduce some expenditures or raise taxes (or borrow more, which implies lower expenditures or higher taxes in the future).

Much of the legal discussion about the ECB has focused on the need to keep fiscal policy and monetary policy apart. Do the ECB's policies violate the Treaty because they have implications for government budgets? Unless one goes into details, this discussion is meaningless because monetary policy necessarily has implications for government budgets. This follows directly from the fact that governments have a claim to the profits that the central bank earns and distributes.

\subsection{Democratic Legitimacy, Fiscal Dominance, and Central Bank Independence}

Do the fiscal implications of central banking warrant or even mandate a subordination of central bank policy to the wishes of democratically elected governments? This has been the view of many governments in the past. This view is also implicit in the German Constitutional Court's reference to the need for parliamentary approval of any policies that might carry substantial budgetary risks.

In Germany, of course, the experience with political control over central bank policies has been a reason to make the central bank independent. Twice in the twentieth century, the political authorities have used their influence over central bank behavior to obtain government funding through the printing press. The seigniorage from the printing of new money, in addition to whatever returns the central bank might earn, provided them with a way to fund expenditures for armaments and wars by means other than taxes. And twice, the result has been a destruction of the currency and a complete expropriation of the holders of nominal assets.

To be sure, in Germany, the independence of the central bank was imposed from outside, by the Dawes Plan in 1923 and again by the Allies in 1948/1951. However, given the experience of the past, the independence of the Bundesbank has always enjoyed strong support in the population, which was more concerned about inflation than about the question how central

25 As documented in the Appendix to Goodhart (1988), most central banks initially had at least some private shareholders. Some central banks still do so today. 
bank independence might be compatible with the democratic-legitimacy mandate of the constitution.

In other countries, the view that central bank policy must be subordinated to the political authorities has sometimes also led to a regime of fiscal dominance whereby the government's funding needs determined the central bank's money creation. Under the Bretton-Woods regime, before 1973, this mechanism was constrained by the need to maintain the exchange rate. $^{26}$ After 1973, however, it led to substantial money creation and substantial inflation in many countries. Political authorities everywhere tried to avoid hard choices by using money creation and the "inflation tax" as a way to maintain expenditures that were popular with important clienteles without raising explicit taxes.

The experience of the 1970s and 1980s however showed that fiscal dominance and inflation may harm economic performance, in particular economic growth. The experience of these two decades also showed that central bank independence provides some protection against the harm from fiscal dominance. ${ }^{27}$

\subsection{The Problem of Time Inconsistency}

From the perspective of economic theory, the issue is simple: The value of seigniorage that is obtained by issuing money depends on investors' expectations of inflation, which lowers the real rate of return on this money. The issuer should therefore have an incentive to promise that the value of money will remain stable and will not be diluted by new money creation. However, once the money has been created and "sold", the issuer has an incentive to breach his promise and create yet more money. If the issuer is under the influence of the finance minister, the incentive is likely to be even stronger because, unless the system enters into hyperinflation, ${ }^{28}$ money creation and the inflation that it induces reduce the real burden of the government's debt, which is denominated in units of money.

Decisions about money creation involve a problem of time inconsistency. Because of this problem, decision makers may not want to stick to promises or threats they made previously. If the decision maker is unable to commit his subsequent decisions beforehand, his very sovereignty over subsequent decisions may make him worse off because nobody trusts him. By delegating subsequent decisions to a third party, such as an independent central bank, he loses sovereignty over those decisions, but this very loss of sovereignty may serve as a mechanism

26 The exception to this rule was the Federal Reserve. Because the dollar was the reference currency for exchange rates, US authorities did not see themselves as being under any obligation to intervene in support of exchange rates. Whereas the Treasury-Fed Accord of 1951 had given the Federal Reserve the freedom to conduct monetary policy without instructions from the Treasury, it did in fact monetize a large part of the federal debt, usually under the auspices of maintaining low interest rates. See Sargent and Wallace (1981), Thornton (1984).

27 See Grilli et al. (1991), Alesina and Summers (1992).

28 The lag between the collection of taxes and the activities that are being taxed implies that real government revenue is actually reduced if inflation is too high. This is the so-called Tanzi effect; see Tanzi (1969). 
of commitment that enables him to benefit from the trust that such commitment induces. The price stability mandate of the Treaty embodies this commitment.

In the academic literature, the time consistency problem for monetary policy is usually discussed in terms of price stability versus employment concerns. Presumed tradeoffs between inflation and unemployment are different depending on whether one is looking at them ex ante, before nominal wages have been set, or ex post, when nominal wages have been set and any increase in commodity prices lowers real wages and may therefore raise employment. In this argument, the time consistency problem concerns the central bank's ability to commit itself vis-à-vis the parties involved in setting wages. Ex ante, the central bank may want to convey the impression that inflation will be low so that wage increases are moderate. Ex post, however, once wages are given, the central bank, on its own or under pressure from the political system, may want to inflate anyway in order to reduce unemployment. The employment effect is however illusory if wage settlements anticipate the subsequent changes in attitudes towards inflationary policy. ${ }^{29}$

The time consistency problem associated with seigniorage from money creation and with government funding is more fundamental. This time consistency problem arises regardless of how contracting in the economy is organized. It is due to the fact that money is a durable asset and the central bank a durable-goods monopolist. Any durable goods monopolist must deal with the difficulty that the demand for his product today depends on people's expectations of his behavior tomorrow. ${ }^{30}$

\section{$3 \quad$ Financial Stability and Monetary Policy}

From a historical perspective, the Treaty's unique focus on price stability reflects the situation of the early 1990s and the preceding history. One hundred years earlier, this formulation would have been inconceivable. Stability concerns had an important place in the mandates of central banks even then, but they concerned the microeconomics of the note issue, interest rates, or financial stability, rather than the overall macroeconomy. Today's focus on "stability” in terms of the macroeconomy is a product of the twentieth century.

\subsection{Stability Mandates Before the Rise of Macroeconomics ${ }^{31}$}

Central banks have always been political. They have been connected to governments, obtaining public funds as deposits and lending to governments. Moreover, they have worked under government charters and benefited from government-granted privileges such as the monopoly

29 See, in particular, Barro and Gordon (1983 a, b).

30 On durable goods monopoly, see Coase (1972). Hellwig (1985) applies Coase's argument in the context of money creation.

31 Most of the discussion in this section is based on the comprehensive historical description and analysis, in Goodhart (1988). Baltensperger (2012) provides details about the origins of central banking in Switzerland. 
on issuing notes. Sometimes their government gave them explicit stability mandates. The Banque de France, for example, was given the task to stabilize the discount rate. ${ }^{32}$

Being political, central banks did not behave like private profit-maximizing firms. According to Goodhart (1988), this fact, together with their being close to their governments, contributed to their acquiring a central position in the financial system, including their becoming the banks for other banks. In the course of this development, they came to take on the role of a lender of the last resort, providing the other banks with liquidity at times of stress when market funding mechanisms were breaking down. ${ }^{33}$ This role came to be enshrined in Bagehot's (1873) famous prescription that central banks should be prepared to lend freely to solvent banks, against good collateral and at penalty rates.

As businesses, however, central banks could not just pursue whatever political mandates they had but needed to take heed of the constraints that markets imposed on them. If the notes you issue are a kind of debt that you must honor, political mandates may not be compatible with the need to avoid default.

From a business perspective, a lender-of-the-last-resort role can actually be good policy. Having the banks that benefit from this role as customers enlarges the funding base. Intervening to maintain financial stability in a time of crisis may help the central bank to avoid losses on its own asset portfolio, as well as provide support for other financial institutions. ${ }^{34}$ Moreover, if the conditions are as strict as the Bagehot rule suggests, the intervention itself is likely to be profitable.

Such a congruence of business interests and stabilization concerns of the central bank cannot be taken for granted however. In the past, there have been recurrent tensions between political desires for stability and the need to maintain convertibility. ${ }^{35}$ An example is the famous interest rate mechanism under the gold standard. High interest rates might be problematic for the finance minister, for financial institutions, or for the overall economy, but they might seem necessary to a central bank that is concerned about its gold reserves. This attitude played an important role in the interwar period and contributed greatly to the extent of the great depression of the 1930 s. $^{36}$

32 Goodhart (1988), Appendix on Banque de France, 114 - 122, especially 118.

33 Goodhart (1988) argues that purely private solutions to the problem of liquidity provision at times of stress had been hampered by the competitive interests of the participating private banks.

34 Policy discussions about the risks of central bank interventions for the central bank's balance sheet typically neglect the fact that abstention from intervention can also be very risky.

35 Goodhart (1988).

36 Eichengreen (1992) 


\subsection{The Impact of Macroeconomics}

The Great Depression of the 1930s had a profound effect on our thinking about the role of central banks. The question whether central banks could have done anything to prevent or to mitigate the disaster arose even as the depression was going on.

Subsequently, the question of what is the role of monetary policy became a key concern in the newly developing field of macroeconomics. In this context, the focus was no longer on the behavior of the central bank as a business in the center of the financial system, but on the role of monetary policy in macroeconomic stabilization.

Such a shift of focus was possible because convertibility of the currency into gold was no longer an issue, and, for the United States at least, where much of the discussion took place, maintenance of the exchange rate under the Bretton-Woods system was not a concern because the dollar was the major reserve currency; maintenance of the exchange rate was an obligation for other countries. And when Mundell (1962) showed that the obligation to maintain a fixed exchange rate imposed constraints on the central bank that harmed or even eliminated its ability to contribute to macroeconomic stabilization, this finding provided an argument against fixed exchange rates and contributed to the momentum of the movement towards flexible exchange rates that culminated in the 1973 abandonment of the Bretton Woods system.

In the second half of the twentieth century, the major debates about monetary policy have all focused on macroeconomics. Is monetary policy or fiscal policy better suited to stabilize or even to permanently increase aggregate demand? Can an inflationary monetary policy be used to reduce unemployment permanently? To what extent is monetary policy influenced by fiscal policy and by the need to monetize government debt, if the central bank wants to prevent "excessive" increases in interest rates? These are the debates of the sixties, seventies and eighties, reflecting the different experiences of the times. ${ }^{37}$ They are concerned with aggregate economic activity and growth, unemployment, and inflation as ultimate policy objectives but pay little attention to the details of what central banks actually do and how what they do affects those ultimate objectives.

Legal norms like the Humphrey-Hawkins Bill in the United States, with its reference to maximum employment, stable prices and moderate interest rates, reflect this thinking. So does the exclusive focus on price stability in the Bundesbank Law and in the Maastricht Treaty. The focus is different but the ultimate policy objective of central bank policy is formulated in abstract terms that are far removed from the microeconomics of what the central bank actually does.

37 The debate on monetary versus fiscal policy may have contributed to the mistaken notion that monetary policy does not have fiscal implications. Concerns about the government budget constraint seem to have been no more than a side issue; see, for example, Tobin (1963), Blinder and Solow (1973), Sargent and Wallace (1981). 
This is also true of the debates about intermediate targets of monetary policy, interest rates, monetary aggregates, or inflation rates. In these debates as well, the microeconomics of what a central bank does, do not play much of a role nor does the financial sector. Debates about transmission mechanisms get a bit closer but even these debates rarely provide us with a comprehensive picture. Characteristically, the dynamic stochastic general-equilibrium models that nowadays serve for quantitative analysis typically do not even have much of a banking sector. $^{38}$

\subsection{What is "Money"?}

In the macroeconomic debates about monetary policy, there always is a question as to what we should think of as "money" and "monetary policy". This question played a prominent role in the early debates about the role of monetary policy in the Great Depression. According to one view, which by now is regarded as obsolete, monetary policy in the Great Depression was expansionary but powerless. This view would be based, for example, on the observation that, in the United States, from 1929 to 1933, an increase in the monetary base, i.e. the amount of central-bank money, by some 15 percent could not prevent a decline in nominal income by 53 percent and in real income by 36 percent. Against this view, Friedman and Schwartz (1963) observed that, even as central-bank money rose by 15 percent, what they called the "money stock", the sum of deposits and currency held by the non-bank sector in the economy, fell by 33 percent. They inferred that monetary policy actually was contractionary and that the monetary contraction was responsible for the economic decline.

As an analytical concept, the concept of the "money stock" is problematic because it mixes elements of central-bank policy, bank behavior, and behavior of non-banks without providing a proper analysis of the different actors interact or how the demand and supply of the different components are determined. ${ }^{39}$ However, this concept provided Friedman and Schwartz with a simple rhetorical device that allowed them to refer to monetary policy as being contractionary when in fact the monetary base was expanding, albeit not enough to compensate for the effects of banks' and non-banks’ increased desires to hold central bank money.

The semantic issue is very much alive today. In the years since 2007, central-banks have very much increased their money issues, but most of these increases just counteracted the contractionary effects that arose from within the economy. For example, in the euro area, the mone-

38 For a similar criticism, see Howitt (2012). Even those models that do fail to take account of the fact that asset markets and bank funding markets operate on a different time scale than goods markets and labor markets. Whereas asset markets and bank funding markets operate in real time, goods markets and labor markets, which concern macroeconomic flows rather than stocks, are more usefully analyzed with a periodization of a quarter or a year; see Hellwig (2014b) On the difficulties of integrating different types of markets in one model and of accommodating the different roles of money in this model, see Hellwig (1993).

39 For example, should we think of non-banks as treating currency and deposits as complements or as substitutes? The definition of the money stock M1 involves the sum of the two, which suggests that they should be seen as substitutes. However, the currency-deposit ratio is treated as a parameter, which suggests that they should be seen as complements! 
tary base rose by approximately 100 percent from 2008 to 2013, but monetary aggregates rose by much less, $\mathrm{M}_{3}$ for example, by about 10 percent, i.e., 2 percent per year, in line with the ECB's inflation target. Observers who focus on the monetary base are convinced that these policies were highly inflationary; observers who focus on $\mathrm{M}_{3}$ assert the opposite.

Behind the discussion, or lack of discussion, about the semantics of the word "money", there are some important substantive issues. If the ultimate objectives of monetary policy are formulated in terms of variables relating to the overall macroeconomy, which variables provides with reliable indicators of conditions in the monetary system? And to what extent should the assessment of these indicators take account of changes in the financial sector?

The empirical evidence seems fairly clear: Whereas in normal times the monetary base, i.e., the amount of central bank money in the economy is a reliable indicator of monetary developments, this need not be the case in times of change or of turmoil in the financial sector. The historical account of the Great Depression in Friedman and Schwartz (1963) provides one example, the recent experience another. In the euro area, for example, cumulative inflation in the period 2008 - 2013 has been about 10 percent, roughly in line with growth in $\mathbf{M}_{3}$ - and with the ECB's inflation target. ${ }^{40}$ On other occasions, when institutional changes that enabled banks to economize on their reserves of central-bank money have caused wider monetary aggregates to grow more quickly than the monetary base, inducing inflation at a higher rate than one might have predicted from the growth of the monetary base. ${ }^{41}$

To be sure, such unreliability of indicators due to structural change must be a concern with any monetary aggregate. For example, in the 1970s in the United States, behavioral changes leading to private households and firms substituting demand deposits by shares in money market funds or in interest-bearing accounts implied that standard monetary aggregates were under-predicting inflation. However, this just means that monetary policy must be attuned to the overall development of the monetary and financial system, and should not be mechanically tied to any one indicator.

The common denominator of these observations is that in any assessment of the likely effect of monetary policy on its ultimate macroeconomic targets the central bank must be aware of changes in the financial sector. A central bank that takes its ultimate policy targets seriously must take this into account. The focus on macroeconomic variables as ultimate objectives of central bank policy is a luxury that was made possible by the elimination of convertibility and by the introduction of flexible exchange rates, but this focus is problematic if it makes us forget about the microeconomics of central banking and the transmission mechanism.

40 In this context, Bundesbank (2012) which warns of inflation, suggests that the jury is still out because lags are long and variable, without however explaining why the monetary base would be more appropriate as an indicator of monetary policy than one of the wider monetary aggregates.

41 An example is given by the experience of Switzerland in 1988 and 1989 when the introduction of electronic interbank clearing and a change in liquidity requirements enabled banks to significantly reduce their reserves of central-bank money. See Baltensperger (2007). 


\subsection{Back to Financial Stability as a Concern of Monetary Policy}

At this point, we come back to the financial stability issues that originally did have a prominent place in central banking and were somewhat shoved aside by the rise of macroeconomics, to some extent because they were moot in the decades between the 1930s and the 1970s when there were no financial crises. When Friedman and Schwartz (1963) talk about monetary contraction due to changes in the reserve-holding behavior of banks and in the currencyholding behavior of non-banks, they are really referring to the banking crises during the Great Depression, to their impact of the "money stock" and on the real economy. The behavior changes that Friedman and Schwartz (1963) document can certainly be attributed to banks' taking precautions against runs and to non-banks' becoming more suspicious of bank deposits. The latter presumably was a result of non-banks' seeing many banks go into default, the former a result of banks' seeing other banks being run upon by anxious depositors.

One may wonder whether the impact on the "money stock" that is discussed in Friedman and Schwartz (1963) properly identifies the transmission mechanism. Today's thinking about the matter seems more strongly influenced by Bernanke's $(1983,1995)$ interpretation that bank defaults and closures destroyed the information capital that banks had accumulated in dealing with their loan customers is also plausible. The credit channel is taken to be the key to the transmission of monetary policy to the nonfinancial sector of the economy. ${ }^{42}$ However, the distinction is less important than the common conclusion that banks are an important part of the monetary system and the monetary transmission mechanism, and that bank failures had a strong negative impact on the monetary and financial system in the Great Depression.

The experience of 2007 - 2009 reconfirms this view. It shows that, despite the more macroeconomic orientation of monetary policy, financial stability concerns remain very relevant for central banking.

\subsection{Do We Need a Financial Stability Mandate?}

Given that financial-stability concerns are often not mentioned in the legal mandates of central banks, we must ask whether they should be mentioned. In practice, in recent years, many interventions supporting financial stability have been undertaken without such a mandate, usually on the grounds these interventions were called for by the given macroeconomic mandates, for example the maximum employment mandate in the United States or the price stability mandate in the euro area (with the presumption that "price stability" requires a prevention of deflation as well as inflation). A special financial stability mandate might therefore seem unnecessary, and might be seen to contribute to moral hazard from the availability of centralbank support. However, while this approach has worked in practice, it has also contributed to political controversy about central bank policies, especially since the semantics of the terms “money” and “monetary policy” are ambiguous. 
More importantly, there is also a deeper issue. If central-bank actions supporting financial stability are justified with a view to the central bank's macroeconomic mandate, actions that endanger financial stability might also be justified with a view to the central bank's macroeconomic mandate. A central bank that sees its macroeconomic mandate endangered because private banks are very cautious might be tempted to ask the private banks to take more risks. For example, if, at the onset of a recession, private banks are becoming cautious in their lending, a central bank that wants to smooth the recession might put pressure on the private banks to be less cautious. ${ }^{43}$ If lending in bad times is actually risky, such behavior can contribute to subsequent financial instability. Moreover, this instability is likely to involve problems of bank solvency, not just bank liquidity. ${ }^{44}$

Similarly, if the central bank has a sense that the private banks' desire to hold reserves of central-bank money impedes their lending to non-financial firms and indirectly harms the central bank's macroeconomic mandate, pressures to change this behavior may entail risks for future financial stability, either from the additional lending or from the fact that sources of liquidity other than deposits with the central bank are less reliable.

Regardless of whether the central bank's macroeconomic mandate is formulated in terms of price stability or in other terms, subsuming financial stability under this mandate is problematic because in some situations the two mandates can be in conflict. It is desirable to bring the conflict into the open.

This consideration suggests that an explicit financial stability mandate would be desirable. To be sure, a double mandate, for financial stability as well as price stability, raises questions of accountability. However, these questions must be asked anyway. If the mandate of the central bank is defined solely in terms of price stability, and financial stability concerns enter if and only the central bank is willing to subsume them under the price stability mandate, accountability is also unclear. If the central bank has a double mandate, it will at least be forced to account for how its policies relate to each of the two dimensions of stability

\subsection{What about Bagehot's Rule?}

We have now come full circle from Bagehot's analysis of the lender of the last resort to a more macroeconomic focus on price stability, inflation, and in some countries employment, and back from macroeconomics to a concern for financial stability, the latter on the presumption that, without financial stability, there is little hope for macroeconomic stability. What

43 Episodes of this sort have been reported about the Federal Reserve under Alan Greenspan; see, e.g. Woodward (2000).

44 As discussed in Hellwig (2014b), a similar conflict can arise in macro-prudential policy: Should we think of macro-prudential policy as a policy intended to stabilize the macroeconomy or as a policy intended to stabilize the financial sector. In a recession, encouraging weak banks to lend may contribute to stabilizing the macroeconomy while putting the banks even more at risk and endangering financial stability. On this point, see also the discussion in Section 4 below. 
about Bagehot's rule then? Lend freely to solvent banks, against good collateral and at penalty rates.

Bagehot's rule addresses three concerns: First, the central bank should invest prudently in order to avoid risks and losses from its assets as much as possible. Second, the central bank should minimize moral hazard from expectations that banks will be bailed out. Third, the central bank should not prevent the closure of insolvent banks.

All three concerns are important but one may wonder why there is no discussion of tradeoffs. The benefits from central bank intervention are not mentioned. The prescription to lend freely in a liquidity crisis is motivated by the desire to limit the crisis and is presumably justified by the benefits from doing so. Why then do we not see a tradeoff between costs and benefits in the rule?

Putting the question differently: Could it be that, in some crises, it might be appropriate to depart from the rule and to lend even to banks whose solvency is in doubt, even against poor collateral and at low rates? This is of course what central banks have done in the recent crisis.

An example from history may illustrate the point. ${ }^{45}$ The German banking crisis of 1931 began with a run on Danat Bank, which was greatly exposed to the fallout from the bankruptcy of Nordwolle, a large textile company. The Reichsbank continued to lend to them through its discount facility even though it must have been clear that Danat Bank was insolvent and even though the collateral no longer satisfied the Reichsbank's usual criteria. At some point, the Reichsbank had to stop doing so because it hit the limit set by the requirement that 40 percent of its money issue must be covered by gold and foreign exchange. At that point, there was a universal run, and the banks had to be closed. The consequences of the crisis for the overall economy were terrible. Over the six months that followed, the economic depression became much worse.

In this episode, developments in the months after the crisis suggest that it would have been better if the Reichsbank had been able to continue its support of banks. Does that assessment include Danat Bank? Or should the Reichsbank have stopped its support for Danat Bank as soon as the bank's solvency was in doubt? One might argue that, if the Reichsbank had not supported Danat Bank, it would not have hit the 40 percent limit for the coverage ratio and the peak of the crisis would have been avoided. But that argument merely diverts attention away

45 For accounts of the episode, see Born (1967), Schnabel (2004, 2010). Schnabel emphasizes the moral hazard involved in the large banks' reliance on the Reichsbank's discount facility, which was based on a long tradition of preferential treatment for these banks. In contrast to Schnabel, Ferguson and Temin (2004) emphasize that the 1931 crisis involved a macro shock, namely the run on the Reichsmark that was triggered by Chancellor Brüning's call for a moratorium on German reparations. The day by day account of the crisis in Born (1967) suggests that the effects of the Brüning speech were subsiding when the Nordwolle bankruptcy reignited the run on Danat and Dresdner Bank. Schnabel's bank-by-bank data analysis also shows that Berliner Handelsgesellschaft, which had more foreign funding than the other banks, yet was better able to withstand the storm because they had better liquidity and moreover their solvency was not in doubt. 
from the substantive question whether a financial stability mandate, in particular one that is justified by macroeconomic concerns, might not justify a departure from Bagehot's rule.

If we base our reasoning on the ultimate macroeconomic objectives, the answer seems clear: If the danger of a crisis is very large, then even a support of banks whose solvency is in doubt may be warranted because, in terms of the ultimate objectives, the costs of a default might be too large. Concerns about risks and losses from the central bank's intervention, as well as concerns about moral hazard from the central bank's availability, are very important, but these concerns must be present in all central bank decisions and must be treated as a part of the tradeoffs that the central bank is facing. ${ }^{46}$ As one is taking account of the tradeoffs, the actual decisions will depend on assessments of costs and benefits in the given situation, and, if the situation is serious enough, concerns for damage prevention may justifiably outweigh the concerns about moral hazard and credibility.

For the concern that central bank support should not prevent the closure of insolvent banks, the argument is less clear-cut. By preventing the closure of an insolvent bank, the central bank may avert an immediate crisis, but it leaves an important problem unsolved. Banks that are insolvent or that are on the verge of insolvency create problems for the health of the industry and for the overall economy. If they behave defensively, trying to cover up losses on their assets, they are likely to engage in poor lending strategies, wasting resources and harming economic growth. ${ }^{47}$ If there is excess capacity in the industry, the preservation of insolvent banks keeps the problem alive and may force all banks to pursue excessively risky strategies in order to survive in an intensely competitive environment. ${ }^{48}$ In either case, a support from the central bank that allows the solvency problems of banks to persist bears significant risks for the longer run, for financial stability and for the ultimate macroeconomic objectives of monetary policy. ${ }^{49}$

\section{Moral Hazard and Prudential Supervision}

Moral hazard and other forms of malfunctioning in the financial sector should in principle be contained by prudential regulation and supervision. Ex ante, prudential supervision should help contain the buildup of risks. Ex post, when risks have materialized, the supervisors

46 In this context, it is worth noting that concerns about risks and losses on assets are less of a concern in a paper money regime with flexible exchange rates than in a regime in which the central bank's notes are genuine debt and the central bank itself can be in danger of defaulting.

47 This effect figures prominently in the Japanese crisis of the past two decades. See Hoshi and Kashyap (2004, 2010). Caprio and Klingebiel (1996, 1997) show that quite generally, delays in the resolution of banking problems can be very costly and very damaging.

48 An example of this effect can be found in covered-bond finance after the 2005 change in legal rules in Germany, which facilitates entry. In subsequent years, competition in this segment of the industry was so intense that participants could only survive by engage in extreme maturity transformation for the funding of the excess coverage. Banks like Dexia and Hypo Real Estate, which did not have much of a deposit base, had to do this through wholesale markets and were therefore extremely vulnerable to problems in these markets.

49 For a comprehensive treatment, see ASC (2012). 
should help contain the damage. In particular, they should make sure that solvency problems are promptly dealt with.

\subsection{The Problem of Hidden Insolvencies}

However, to deal with solvency problems, one must first identify them. This may be difficult because, unlike default, insolvency is a theoretical concept which is difficult to verify in practice. By a standard criterion, a firm is insolvent if the value of its assets is less than the value of its liabilities. If this criterion is met, we infer that, at some point, the firm will not be able to pay its debts, and we conclude that the situation should be remedied right away. Early intervention would avoid further damage that might arise because borrowers facing a prospect of bankruptcy have highly distorted incentives. ${ }^{50}$

But comparing the values of assets and liabilities is anything but clear-cut. What is the value of assets when there are no market prices? For example, what is the value of an assembly line in an automobile factory? As a going concern? In liquidation? And what is the value of a loan in a bank's books? Even if market prices are available, should we take them seriously? Or should we say that these valuations are depressed by panic and fire sales? ${ }^{51}$ If Lloyds Bank found it appropriate to sell a portfolio of shipping loans at a 50 percent discount, should we require that all banks apply such a discount to their shipping loans? ${ }^{52}$ Or should we accept the view that the shipping crisis will soon be over and, if these loans are held to maturity, losses will be much smaller? ${ }^{53}$

In the absence of market prices, valuations require forecasts, and these forecasts involve an element of discretion. Incumbent managers and owners tend to use this discretion to their advantage, claiming that "appropriate" asset values are high, and the firm has no solvency problems. By this procedure, they may keep the firm going until it actually defaults because it no longer has the cash to meet its commitments.

In the case of a bank, default may come quite early because the bank's short-term funding may disappear if creditors are afraid that the bank might be in trouble. The bank's managers may then assert that the bank has only a liquidity problem and appeal for emergency liquidity assistance to overcome this problem, which it claims is just temporary. The central bank must then ask itself how justified the appeal is. For this purpose, it needs an assessment of what the bank's assets actually are. This is where the supervisors come in.

50 For a detailed account of problems from hidden insolvencies, see Admati and Hellwig (2013), Chapter 3.

51 This was a key issue in the discussions about fair-value accounting in 2008/2009. See IMF (2008).

52 Reported by Handelsblatt, April 20, 2013.

53 This was the view of the Hamburg government in 2013, when it asked the legislature to approve an increase in the government's second-loss guarantee for HSH Nordbank from 7 billion to 10 billion euro. For a critique, see Hellwig (2013) 


\subsection{Forbearance and Procrastination}

If the bank in question is small and if there is a prospect that the problems can be eliminated without further repercussions, the supervisors are likely to deal with the matter very promptly. A typical example would be a regional bank of moderate size that can be sold to a larger bank, which is happy to use the occasion to expand its deposit base.

The matter is different if the bank in question is important in size, systemic relevance or political influence, and if the supervisor sees no way of dealing with the problem without generating major turmoil. In this case, the supervisor may well join the bank's managers in assessing its assets, e.g., nonperforming loans as being more valuable than they really are. Closing one's eyes to the fact that the creditworthiness of loan customers and collateral values are questionable may be a convenient way to avoid disagreeable and costly interventions. From the perspective of the central bank, which is expected to act as a lender of the last resort, this is a second layer of moral hazard, now at the level of supervisory activity.

There are several reasons for this moral hazard. First, intervention is always costly. If a bank is in serious trouble, dealing with the matter by a recapitalization requires money, and a resolution may bring turmoil to the economy. Moreover, governments and supervisors must deal with public scandal as people ask why the problems have been allowed to arise and why they have not been dealt with before. Kicking the can down the road and hoping for the best may therefore seem like an attractive alternative.

If the banks in question are extremely large or if there are very many of them, the problem may also be too big to handle because the public funds needed to avert the negative fallout from the crisis may exceed the government's fiscal capacity. Thus, when the Swedish government intervened very promptly to clean up the banking system in 1992, it lacked the fiscal capacity to also smooth the recession (which however was short, thanks to the cleanup of the banking sector and to the trade effects of currency devaluation). Limited fiscal capacity has also played a major role in the handling of banking problems in some countries in the euro area since 2010.

Second, banks are political. This is especially true of public banks like the German Landesbanken, whose lending policies are often tailored to the interests of the regional governments that own them. More generally, many political authorities (and their voters) think of banks as institutions that should serve to fund their policies, promoting the government's industrial policy or simply funding the government itself. ${ }^{54}$ In some cases, governments' industrial policies have been focused on the banks themselves, using financial institutions that attract funds from the rest of the world and invest funds in the rest of the world as a tool for creating highly-paying jobs very quickly. ${ }^{55}$ With such a policy stance, governments are not likely to engage

54 For a more detailed discussion, see Chapter 12 in Admati and Hellwig (2013).

55 This has been the experience of Iceland, Ireland, and Cyprus. More traditional financial centers, such as the United Kingdom or Switzerland have also seen economic growth fuelled by promoting the financial sector as an export industry but their dependence on this sector has been somewhat less pronounced. 
in active interventions that would force the banks to lay open their losses and either recapitalize or retrench their activities. And the supervisors are likely to be pressured into taking a passive stance towards these banks.

Forbearance and procrastination are likely to be reinforced by fiscal concerns if a government is financially squeezed and a recapitalization of weak or insolvent banks would impose a large fiscal burden. This effect is even stronger if the government expects the central bank to step in, providing commercial banks with cheap loans in order to support the monetary system. And, as mentioned in the introduction, the effect is stronger yet if central banking is supranational and banking supervision national so that the costs of central bank intervention are partly borne by others. ${ }^{56}$

\subsection{Light-Touch Regulation and Supervision Ex ante}

These concerns about supervision are not limited to forbearance ex post. Similar concerns arise with respect to supervisory behavior ex ante, at a time when the risks are building up. According to a well-known saying, it requires courage to take away the punch bowl while the party is going on. This saying applies to supervision as well as the monetary policy that may have fuelled the buildup.

As a matter of principle, supervisory intervention that puts a brake on new business developments may seem contrary to the principles of a market economy, which require that privatesector institutions be allowed to innovate, which is inherently risky. In some countries, this concern has a legal dimension. If new practices have not been explicitly prohibited, the supervisor may not have the legal authority to do anything about them. ${ }^{57}$

Even if supervisors do have the requisite legal authority, their governments may prevent them from using it. In the years before the financial crisis, "light-touch regulation" was a major selling point by which some countries built up their financial industries. This light-touch regulation contributed significantly to the risky practices that banks in those countries pursued and also contributed significantly to the problems these countries have experienced in 2008 and subsequently. Even in countries that did not pursue this kind of industrial policy, political concerns for politically important banks seem to have affected supervisory behavior in the years before the crisis, with significant consequences for the extent of damage in the crisis.

56 For an extensive discussion of such externalities in the euro area, see Hellwig (2014a).

57 For example, the German supervisor has claimed that he lacked the legal authority to prohibit the regulated banks' providing large guarantees of liquidity guarantees to their off-balance-sheet special purpose vehicles that enabled them to hold vast amounts of asset-backed securities and CDOs without equity; by the letter of the law, such guarantees did not come under existing large-exposure rules because their maturities were less than a year; never mind that the assets that needed to be funded had longer maturities. Given the German tradition of administrative law, which is hostile to extensive exercises of judgment on the part of administrative authorities, the supervisor's assessment of the legal situation may actually have been correct. Such country-specific legal traditions may cause problems for the Single Supervisory Mechanism, which in the area of European Directives applies the national laws that implement these directives, presumably subject to national judicial review. See Hellwig (2014 a). 


\subsection{Systemic Risk and Macroprudential Supervision}

At a deeper level, in the past, supervisory perception of problems ex ante has been hampered by the focus on individual institutions that characterizes traditional "micro-prudential supervision. Such a focus is natural because regulation and supervision are the activities of an administrative authority, imposing certain requirements on individual financial institutions, monitoring these institutions, and taking administrative decisions as to what they can and cannot do. However, as one is looking at risks in individual institutions, one may not see the forest for the trees. Specifically, one may miss the fact that similar exposures at different institutions are creating a risk of a systemic crisis due to a macro shock that affects all institutions simultaneously. One may also overlook the systemic risks that arise from correlations between counterparty credit risks and underlying risks in a complex and highly interconnected system of risk management through derivatives and other hedges. For example, financial institutions and their supervisors seem to have overlooked the fact that, if the credit risks from ABS CDOs were hedged by credit default swaps and if the insurers who provided the hedges had lots of such positions, the underlying credit risks might merely be transformed into the counterparty risk that the insurers might not be able to pay. Needless to say, these counterparty credit risks were highly correlated with the underlying risks. ${ }^{58}$

We may hope that this blind spot will disappear with the further development of macroprudential supervision. ${ }^{59}$ However, macro-prudential supervision requires quite a different perspective. Even if one takes that perspective, one may find it difficult to see new systemic risks that are developing as the financial sector is trying out new strategies. Whereas in the 1970s and 1980s, it might have been enough to observe the parallel exposures of different institutions to conventional macro shocks, from interest rates, exchange rates or the macroeconomy, in the 2000s, much of the macro risk was hidden in a complex network of contracts, where individual institutions and their supervisors overlooked the role of correlations discussed in the preceding paragraph. And everybody overlooked the systemic risks from fire sales and asset price declines imposing losses on all banks that were holding the same kinds of assets.

The very distinction between micro-prudential and macro-prudential supervision is a problem. This distinction may be unavoidable because, as mentioned, on the ground, supervision concerns the individual institution, the micro-level. However, if different institutions are subjected to the same regulatory rules and supervisory practices, these rules and practices have a macro-prudential and macroeconomic dimension. The distinction between micro-prudential and macro-prudential supervision should not lead us to overlook this macro-prudential dimension of micro-prudential supervision. This is a challenge that we have not yet come to terms

58 A comprehensive account of systemic effects in the financial system is given in Hellwig (2014b).

59 Interestingly, the countercyclical provision of the Bank of Spain, which has become the paradigm for macro-prudential regulation seems to have been introduced initially for reasons of monetary policy, i.e., fight inflation when entry into the currency union caused interest rates to fall dramatically, rather than prudential concerns. 
with. The challenge is made more difficult by the fact that, as different institutions are involved in micro-prudential and macro-prudential supervision, the discussion about semantics is also a discussion about turf.

\subsection{The Danger for Monetary Dominance}

The weakness of financial institutions puts the central bank on the spot. If the central bank takes its monetary policy mandate seriously and if it takes account of the role of financial institutions in the monetary system, it has hardly any alternative to a policy of neutralizing the effects of adverse financial developments, which often means providing support to financial institutions or financial markets. In this situation, the independence of the central bank is undermined, not because of any explicit challenge but because a central bank that takes its mandate seriously finds itself in a straightjacket.

Monetary dominance, a regime in which the other actors take the central bank's policy as given and adapt their behaviors accordingly, is then replaced by what I would like to call financial dominance. ${ }^{60}$ By this I mean that central banks take the situation of the financial system as given and adapt their policies accordingly. Sometimes, financial dominance involves a form of hidden fiscal dominance, a situation where the weakness of private banks is due to their having been and being pressured into funding their governments and where central-bank support provides these governments with indirect access to the printing press.

In practice, the distinction between financial dominance and hidden fiscal dominance is often moot because problems in the financial sector and in government finances are linked. In the euro area in recent years, we had both, banking crises that caused sovereign debt crises and sovereign debt crises that caused banking crises. In some countries, for example Greece, oldfashioned sovereign debt crises that had been caused by the failures of political systems to set priorities so as to make ends meet spilled over into the financial sector because sovereign default imposes large losses on creditors and sovereigns had used their powers to induce "their" banks into funding them. In other countries, for example Ireland, equally old-fashioned banking crises that had been caused by boom-and-bust developments in real-estate markets caused sovereign-debt crises when the fallout from the banking problems exceeded their fiscal capacities. $^{61}$

Under the Memoranda of Understanding (MoU) for how to deal with banks in difficulties that were concluded in the early 2000s, solvency problems of banks in the euro area were to be handled by national governments, liquidity problems of individual institutions by the national central banks, and liquidity problems of the entire system by the ECB. ${ }^{62}$ In a situation where both government finance and the banking system are in trouble, this assignment of responsibilities prevents a cleanup in the financial sector. At the national level, the incentives for for-

60 The term was suggested to me by Hans-Helmut Kotz.

61 For detailed accounts of the different kinds of crises, see Hellwig (2011, 2014a).

62 For a critical discussion, see Hellwig (2007). 
bearance and procrastination that I discussed earlier are then particularly strong. If at the same time national governments and supervisors appreciate that those weak banks' access to central-bank funding enlarges their own funding capacity, there is little that the central bank can do about it.

\section{$5 \quad$ Challenges for Institution Design and Policy}

\subsection{Must Supervision Be In the Domain of Central Banks?}

Institutional arrangements for the relation between central banking and bank supervision have forever.been a subject of debate. Goodhart (1988) argues that supervisory functions of the central bank arose naturally from the central bank's role in stabilizing the financial system and, if necessary, acting as a lender of the last resort. The potential for moral hazard on the side of private banks that was thereby induced was recognized early on, and supervision was introduced as a means of containing this moral hazard. However, Goodhart also notes that, in some countries, central banking and supervision have been kept separate from the beginning.

Over time, attitudes to this issue have shifted back and forth. The United Kingdom separated central banking and financial supervision in the 1990s and joined them again very recently. In Germany, when Bafin was created in 2001, the government initially proposed to take all supervisory activities away from the Bundesbank; faced with strong resistance from the Bundesbank, the government kept the previous system of having separate institutions, with Bafin in charge of actual decision making, but inspection activities carried out jointly by the two institutions. ${ }^{63}$ Subsequently, in 2009, the incoming government proposed to put all supervisory activities into the Bundesbank, but the Bundesbank itself demurred when it realized that this task might threaten its independence. Since the crisis, there has been a trend to putting financial supervision into the central banks though there is no evidence that the scope and effects of the financial crisis were any different in countries where banking supervision was with the central bank and in countries where banking supervision was in the hands of a separate authority.

In the euro area, originally, the fact that central banking is supranational and banking supervision national implied that the two were separate as a matter of course. As we are now moving to a banking union, the ECB will be in charge of the Single Supervisory Mechanism (SSM). As far as I can tell, this is not the result of conscious deliberation, but a consequence of the fact that the Euro Area Summit in June 2012 wanted to avoid a Treaty change, which would have delayed the whole procedure. The SSM was created under the auspices of Art. 127 (6)

63 Technically, inspectors are from the staff of the Bundesbank but Bafin has the ultimate say. In a report written for the Federal Ministry of Finance after the financial crisis, Hartmann-Wendels et al. (2010) analyze how this procedure actually works. It seems that, before Bafin actually gets to see the inspectors' reports, a lot of pre -filtering of information takes place within the Bundesbank. On the resistance of the Bundesbank in 2001, see http://www.bundesbank.de/Redaktion/DE/Kurzmeldungen/Stellungnahmen/ 2001_01_25_allfinanzaufsicht_bundesbankstrukturreform.pdf?_blob=publicationFile 
TFEU. Under this article, the ECB can be given specific tasks in banking supervision by a Council Regulation. ${ }^{64}$

Even though the outcome has been determined, it is worth discussing its merits. The following considerations seem relevant: First, given the importance of financial institutions in the monetary system, the central bank must have the best possible information as to what the state of the financial system actually is. This is an argument for having the two activities in one institution. If one has them in separate institutions, one must make sure that the requisite information flows are not unduly impeded by flawed incentives, e.g., concerns about turf or desires to hide bad developments. If the institutions are separate, it seems important to organize the actual inspections so that they are done by both institutions jointly, as is the case with Bafin and the Bundesbank. ${ }^{65}$

Second, to protect the substance of central bank independence, it is important to reduce the scope for moral hazard to erode that independence. As discussed in the preceding section, such moral hazard comes not only from the financial institutions themselves but sometimes also from political authorities. This is an argument for making financial supervisors independent of political authorities, as is done in Art. 19 of Council Regulation (EU) No. 1024/2013, the regulation that creates the SSM. If one fears that a separate supervisory authority might also develop its own agenda, this is also an argument for having supervision directly in the central bank.

However, the substance of central bank independence may also be threatened if the central bank is in charge of supervision and is held responsible for any problems that might arise in the financial sector. In this case, the central bank itself might delay the resolution of banking problems, hoping that the problems might disappear on their own if enough time is allowed to pass by. The 1990 turnaround in US monetary policy provides an example, moreover one where a policy of delay and support to the system was successful. However, as mentioned above, delay is not always the best strategy and one must fear that some of the incentive distortions that bias such decisions will affect central bankers as well as supervisors in separate institutions. Indeed, the distortions can be larger, if the central banker puts more weight on the immediate macroeconomic and monetary situation and discounts the costs to future financial stability.

These concerns are particularly relevant if the central bank is tempted to use its power over financial institutions to make these institutions take actions that may seem desirable from the central bank's own macroeconomic perspective but are problematic for the institutions' safety. Above, I discussed this problem in the context of what is the relation between the central bank's macroeconomic mandate and financial stability. Even if the central bank has a financial stability mandate, there is a problem as to how it manages the tradeoff when the two

64 As an outsider to the legal community, I was somewhat amazed to see that a norm that allows the ECB to be given "specific tasks in banking supervision" would be a sufficient for putting it fully in charge.

65 See Hartmann-Wendels et al. (2010). 
mandates are in conflict. This problem is particularly pronounced if the pressure that the central bank can put on market participants derives not only from its own market power but also from its powers as the administrative authority in charge of supervision.

This brings me back to a point I made in the very beginning. Central banking is a form of banking, not an administrative activity. Supervision is an administrative activity. Putting the two under the same roof raises questions about culture as well as procedure. Administrative activity involves the imposition of statutory authority on individuals and institutions under given legal norms, presumably subject to judicial review. ${ }^{66}$ By contrast, central-bank policies are implemented by market transactions where counterparties are in principle free to decide whether they wish to participate or not. These are two very different modes of procedure. If integration of the two activities is all too complete, it might happen that, by threats or by promises, administrative practices become part of the "exchanges" of the central bank with its counterparties in the financial sector. As shown by the experience of the United States with the "Greenspan put", such "exchanges" bear the risk of corrupting the governance of both, supervision and monetary policy.

To avoid these risks from having central banking and supervision under the same roof, it is important to develop institutional arrangements and procedures that maintain the requisite separation of administrative activities from central banking activities while making sure that the central-banking side of the institution gets all the information it needs about the state of the financial system. In particular, relations between the supervisor and individual institutions must be immunized against any influence that is based on how well the institution is playing along with the central bank's monetary policy objectives.

The regulation creating the SSM provides for some such separation. However, the experience with "Chinese Walls" in other institutions suggests that this may be a major challenge. Chinese Walls are not effective just because they are in the rules but because the institution is willing to live by those rules. This is ultimately a problem for the institution's leadership.

\subsection{What Place for Macro-prudential Supervision?}

Institution design is complicated by the distinction between micro-prudential and macroprudential regulation and supervision. The concept of macro-prudential regulation and supervision has been introduced in order to fill the gaps that appeared because traditional microprudential regulation and supervision were focused on individual institutions and paid little attention to the overall system. As yet, however, the scope and objectives of macro-prudential regulation and supervision are unclear.

66 Council Regulation (EU) No. 1024/2013 does not seem to say anything on the subject of judicial review of administrative decisions. This may be a problem, especially since much of the supervisory activity takes place under national law implementing the European Directives. 
As discussed in Hellwig (2014b), the term “macro-prudential regulation and supervision” encompasses (i) Crockett's (2000) notion that we must be worried about correlated exposures of different institutions to macro shocks, (ii) the use countercyclical provisioning as carried out by the Bank of Spain in the years before the crisis, and (iii) a view that a better understanding of systemic risk and macro risk might have led to better policies in the years before the crisis. "Systemic risk" is sometimes identified with risks from the financial system to the macroeconomy, sometimes with risks from the macroeconomy to the financial system, and sometimes with risks of shock propagation within the financial system. As yet, however, we do not yet have an encompassing conceptual framework to understand how these different concerns fit together and how they relate to either micro-prudential regulation and supervision or monetary policy.

Macro-prudential supervision involves two distinct activities. One concerns the observation of systemic risks in the economy. This activity differs from both micro-prudential information collection and monetary analysis. In contrast to micro-prudential information collection, the analysis of systemic risk focuses on interdependence between financial institutions or between the financial system and the rest of the economy, rather than individual institutions. In contrast to monetary analysis, the analysis of systemic risk focuses on the micro structure of the financial system, rather than broad aggregates. Because patterns of interplay and interdependence in the financial sector are forever changing, the analysis of systemic risk cannot start from any fixed model of how risk in the financial sector is allocated and how participants in the financial sector interact. Instead, the analysis of systemic risk must start each new day with the question of what is the "story" behind current developments in risk allocation. Conceptually, this approach is closer to monetary analysis than to supervision, but even so, it is a far cry from working with well-established quantitative models with fairly rigid structures ${ }^{67}$.

The other part of macro-prudential supervision concerns the use of macro-prudential tools such as rules for countercyclical capital or liquidity buffers, loan-to-value ratios in real-estate lending, or haircuts and margin requirements. Technically, these rules differ from microprudential rules only in that they fluctuate over time in accordance with the macro-prudential authorities' assessments of the situation. As a practical matter, these rules may even be implemented by the micro-prudential authorities that are in charge of dealing with the individual institutions.

The relation of macro-prudential supervision to, micro-prudential supervision raises the following questions:

67 From my own experience, I would say that the closest analogue is in competition policy where each case must be studied on its own terms, without any preconception about the mode of competition in the particular markets under consideration. Look at the data, see what they imply for abstract concepts such as marginal-cost curves or, for systemic risk analysis, risk shifting between parties, think as to which model or set of models might be useful, consider the implications of different models for observables, and go back to the data to check. If necessary, try to collect additional data. Also, if necessary, repeat the procedure a few times, 
How do the macro-prudential institutions get the information they need? The clearcut distinction between macro-prudential and micro-prudential supervision creates a danger that activities will be compartmentalized and that the macro-prudential authorities will not have access to information about individual institutions that is available to the micro-prudential supervisors. Yet, understanding the risk allocation "story" behind current developments in markets usually requires some information of how individual institutions take risks, hedge risks, and see the risks they are exposed to.

How do the macro-prudential supervisors make sure that micro-prudential supervisors do not counteract their policies? As micro-prudential policies are applied to all affected institutions at the same time, these policies necessarily have a macroeconomic dimension. Unless the decisions of the different authorities are coordinated, there is a danger that micro-prudential policies might neutralize macro-prudential measures.

The relation of macro-prudential supervision to central banking and monetary policy raises the following concerns:

What are the objectives of macro-prudential supervision? Is it to stabilize the macroeconomy by immunizing it from the vagaries of the financial sector? Or is it to promote financial stability, including by immunizing the financial system against shocks from the macroeconomy? As was discussed above, financial-stability and macroeconomic-stability objectives need not always coincide. If the banks are weak and the economy is in a recession, do we want the banks to continue lending, so as to reduce the credit crunch, or do we want the banks to clean up their balance sheets, so as to reduce risks to financial stability?

Some might say that there is no conflict: If the economy goes more deeply into a recession, the weakness of banks will become even greater. Alternatively, if we don't get the banks out of the mess they are in, we cannot expect to achieve a sustained macroeconomic recovery. Seeing these arguments side by side, one appreciates that the question really concerns the dynamics of stabilization policy. Forbearance with respect to the banks' problems may reduce a credit crunch and recession today but bears the risk of an even bigger credit crunch and recession in the future. A cleanup of the financial system today may deepen the recession but bears some hope of a healthy resumption of lending once banks are properly recapitalized. ${ }^{68}$

How do the administrative activities of macro-prudential supervision go together with central banking? The issues are basically the same as for micro-prudential supervision. Whereas central banking and monetary policy are focused on day-to-day policy choices that are mostly implemented through transactions with counterparties on a quid-pro-quo basis, macro-

68 The two alternatives may loosely be described as the Swedish and the Japanese strategies for dealing with the crisis of 1992. The Swedish authorities intervened promptly to clean up their banking system; the cost was a very sharp recession, the return a quick recovery. In contrast, the forbearance exercised by the Japanese authorities towards their banks contributed greatly to the long period of low growth in Japan. See, for example, Hoshi and Kashyap (2004, 2010). 
prudential as well as micro-prudential supervision involves the imposition of administrative rules by government fiat, presumably. These are two very different modes of operation.

In substantive terms, I see a certain danger that, if macroeconomic stability and monetary policy goals dominate, the powers of macro-prudential as well as micro-prudential supervision might be used to impose on banks for monetary policy purposes. Such an approach is problematic, especially if, for monetary policy purposes, banks are encouraged to take additional risks.

As yet, we do not have a clear conceptual framework for dealing with these issues. However, we need such a framework if we are to make sense of institution design.

\subsection{Resolution as The Elephant in the Room}

Whereas some of the concerns about moral hazard in supervision that I raised above are related to politics, in particular, national politics, the issue of how to deal with banks in difficulties poses a serious problem and a threat to central-bank independence no matter how supervision is organized. The most careful and most professional supervisor is helpless if there is no practical way of dealing with problem banks. ${ }^{69}$ The Lehman experience has made us all very sensitive about this issue. We learnt that "Too Big To Fail” is not a myth: Letting a bank fail can indeed have catastrophic consequences, and can be much costlier than a bailout.

Since the Lehman crisis, authorities worldwide have been torn back and forth between two concerns, on the one hand, the desire to avoid a repetition of the post-Lehman panic, on the other hand, the desire to develop procedures for dealing with problem banks that would avoid the kind of tsunami that we saw in September 2008. In the European Union, Banking Recovery and Resolution Directive (BRRD) and the Single Resolution Mechanism (SRM) are part of this program.

However, I am not convinced that the changes in resolution procedures that we have had are really apt to make resolution viable. Many of the reforms that have been instituted, such as the Dodd-Frank Act in the US or the German Bank Restructuring Act of 2010, are likely to prove impractical if we get into another crisis. The BRRD and SRM are hardly better.

I have three main concerns. First, for banks with systemically important operations in different countries, multiple-entry resolution with different procedures in each country where there are legally independent subsidiaries destroys the viability of operating procedures that presume integration. In the case of Lehman Brothers, with integrated cash management, the UK authorities found that there was no cash in the London subsidiary because all cash had gone to New York at the previous close of business. As a result there was no way to even temporarily maintain systemically important functions (market making) in London. I am told that integrate IT systems may pose even more serious problems. 
Second, the BRRD and SRM, pay hardly any attention to the need to maintain funding. Any maintenance of systemically important operations requires funding. Market funding, however, is likely to vanish unless creditors are given guarantees that they will not be harmed. In ordinary insolvency law, the problem is solved by giving new creditors priority over preinsolvency creditors. However, this only works if (i) freezing the old creditors has no dramatic systemic effects and (ii) the need for new funding is small enough for the new funding to be relatively safe if it is given priority. In the case of banks, with enormous amounts of funding from wholesale short-term creditors such as money market funds and with enormous derivatives positions, neither condition is satisfied. As the experience of the Reserve Primary Fund and other money market funds after the Lehman bankruptcy has shown, systemic effects from a freeze of short-term claims can be disastrous, with a run on money market funds forcing these funds to withdraw their own funding of banks and making all participants scramble for cash.

The BRRD tries to avoid such consequences by exempting certain liabilities from "bail-in”, i.e., the assignment of losses to creditors in resolution. In particular, collateralized liabilities and derivatives (up to the value of the collateral) as well as very short-term liabilities to other financial institutions are exempt. Presumably the legislators hope that these exceptions will preclude runs in resolution. I do not share this hope. If a bank is put into a resolution regime, short-term creditors may decide to run even though they are exempt from bail-in. Money market funds may be forced to do so because otherwise their own customers might run, as happened in September 2008. Or they might fear that, through abuses of re-hypothecation and the like, the collateral for their claims might not be sufficient.

The various resolution and restructuring funds that are being instituted cannot provide much help with the funding problem. Maintenance of funding requires guarantees on the order of hundreds of billions of euros. These amounts are much larger than the amounts considered for the various European funds. In the United States, the problem is solved by providing the authority with access to loans from the Treasury. In the European context, however, the fiscal backstops that are in place or under consideration are too weak to provide investors with the assurance they will require.

Third, whereas the numbers involved in solvency problems are likely to be much smaller than funding needs, I still have doubts about the scale of the backstops that are in place or under consideration. I also have doubts whether bail-ins will be as effective as is presumed in the new legislation. In the S\&L crisis of the 1980s in the United States, the industry was in such difficulties that it could not bear the costs of the crisis; the Federal Savings and Loans Insurance Corporation (FSLIC) became insolvent and was merged with the FDIC. Out of \$153 billion of losses, in the end, the industry paid $\$ 29$ billion and taxpayers $\$ 124$ billion. $^{70}$ 
This example may be seen as atypical in that most S\&L funding in the United States. had come from deposits, which were federally insured. Thus there was little room for clawbacks or bail-ins of creditors. One may therefore hope that ultimate losses in bank resolution will be smaller if more creditors are bailed in, i.e., if more creditors are forced to participate in losses as they would have to do if the bank entered a bankruptcy or insolvency procedure. On this point, however, I am not very hopeful, despite the fact that the new legislation contains a "bail-in tool". The Lehman crisis and the post-Lehman bailouts have created a strong lobby against any creditor liability. Forcing creditors to bear losses, we are told, entails a danger of systemic risks from domino effects, as those creditors themselves may be too weak to absorb those losses, or as the realization that creditor liability must be taken seriously hurts funding conditions of other banks.

Given these concerns about resolution, I fear that the problem of forbearance and procrastination in dealing with banks in difficulties will not be resolved by the SSM and the integration of supervision into the ECB. If such decisions are within the purview of the central bank, they will not be subject to the same distortions as they have been so far. However, they will be subject to different distortions. The reasons may be different, but the temptation to kick the can down the road will be there as long as we do not have a resolution procedure that we can trust. In the end, the ECB may be even more in a straightjacket than it was before the introduction of the SSM.

Of the problems I mentioned, the multiple-entry problem will only be solved if have an international accord in favor of single entry. However, this would presume an agreement on how to share losses that gives the participating countries sufficient confidence that their interests will not unduly suffer in the procedure. Unfortunately, such an agreement seems far away.

The funding problem can easily be handled by the central bank itself if it has the assurance that any losses will be covered by a fiscal backstop. In the medium run, I believe that banking union will require some Europeanization of fiscal responsibility for banks. This would somewhat defuse the issue of loss sharing in dealing with banks with systemically important operations in different countries, making single-entry resolution more palatable. ${ }^{71}$ It would also protect the ECB if it were to provide support for funding in resolution.

Most importantly, a Europeanization of fiscal responsibility is necessary for the protection of monetary policy. As long as the assignment of fiscal responsibilities prevents a cleanup of the financial system, the independence of the central bank's monetary policy is undermined by the weakness of the financial sector. 


\subsection{Fiscal Responsibility and the Independence of Supervisory Authorities}

In many countries, traditionally, banking supervision has been in the domain of the finance minister. In the euro area, this is now changed because, under the SSM, all supervisory authorities are independent. This independence may give rise to legal controversy in the future.

The previous arrangement could be justified on the grounds that, if banks that are too big, too systemic or otherwise too important to fail, ultimately, the risks of poor banking supervision are borne by the taxpayer, and therefore the finance minister should be in charge. However, if we look at the actual record of how banking supervision was carried out under the authority of finance ministers, a good case to be made for independence. ${ }^{72}$ As I discussed above, governments have all too often seen their banks as a source of funds rather than a source of risks, using them as both tools and objects of costly industrial policies without much concern for the potential costs to taxpayers. Moreover, in the monetary union, national political sovereignty over financial supervision induces serious distortions if national politicians expect the costs of their actions to be at least partly borne by the central bank.

As a matter of constitutional law, however, the new arrangement, with independence of supervisory authorities, may be questionable. To be sure, there may not be much of a problem if we take the view that never again will taxpayers be called upon to bail out a failing bank. However, as was discussed above, I do not share this view. Even if I leave the funding problem aside, if solvency problems are large enough and if these problems affect the entire industry, a choice will have to be taken between a bailout with taxpayer money or an intervention that may entail substantial risks for the financial system and the overall economy. One might try to avoid the problem by keeping the affected banks going without doing anything, relying on central-bank funding and hoping for a better future, but then the ugly choices may merely be delayed. Once the ugly choice between a recapitalization at the taxpayers' expense and a systemic crisis has to be taken, the question of how independence of supervisory authorities squares with the risks to taxpayers will be on the agenda again. I consider it all the more important that the assignment of fiscal responsibilities and fiscal capacities be speedily reformed and that this be done in a way that actually works rather than one that is merely proclaimed to work. 


\section{References}

Acharya, V.V., and Steffen, S. (2013), “The greatest carry trade ever? Understanding European bank risk”, Working paper, New York University and European School of Management and Technology.

Admati, A.R., and Hellwig, M.F. (2013), The bankers' new clothes: What's wrong with banking and what to do about it, Princeton University Press, Princeton, N.J.

Alesina, A., and Summers, L. J. (1992), "Central bank independence and macroeconomic performance: Some comparative evidence” Journal of Money, Credit and Banking 25 (2), $151-162$.

ASC (2012), "Forbearance, resolution, and deposit insurance”, Report No. 1 of the Advisory Scientific Committee of the European Systemic Risk Board.

Baltensperger, E. (2007), “The National Bank’s monetary policy: evolution of policy framework and policy performance”, in: The Swiss National Bank 1907 - 2007, Verlag Neue Zürcher Zeitung, Zürich, 569-597.

Baltensperger, E. (2012), Der Schweizer Franken: Eine Erfolgsgeschichte, Verlag Neue Zürcher Zeitung, Zürich.

Barro, R. J., and D.B. Gordon (1983a), “A Positive Theory of Monetary Policy in a Natural Rate Model”, Journal of Political Economy 91, 589-610.

Barro, R. J., and D.B. Gordon (1983b), "Rules, Discretion, and Reputation in a Model of Monetary Policy”, Journal of Monetary Economics 17, 101-122.

Bernanke, B.S. (1983), "Nonmonetary effects of the financial crisis in propagation of the Great Depression”, American Economic Review 73 (3), 257-276.

Bernanke, B.S. (1995), “The Macroeconomics of the Great Depression: A Comparative Approach,” Journal of Money, Credit and Banking, 27(1), 1-28.

Bernanke, B.S., and Lown, C.S. (1991), “The Credit Crunch”, Brookings Papers on Economic Activity 22 (2), 205-248.

Bernanke, B.S., Gertler, M., and S. Gilchrist (1999), "The financial accelerator in a quantitative business cycle framework”, in: J. B. Taylor and M. Woodford (eds.), Handbook of Macroeconomics Vol. 1, Ch. 21, 1341-1393, Elsevier. .

Bernanke, B.S., and Gertler, M. (2001), "Should Central Banks Respond to Movements in Asset Prices?”, American Economic Review 91 (2), Papers and Proceedings, 253-257.

Born, K.-E (1967)., Die deutsche Bankenkrise, Piper Verlag. 
Boyd, J.H., and Gertler, M. (1994), „The role of large banks in the recent U.S. banking crisis”, Federal Reserve Bank of Minneapolis Quarterly Review 18 (1), 2-22.

Blinder, A.S., and Solow, R.M. (1973), “Does fiscal policy matter?” Journal of Public Economics 2 (4), 319-337

Bundesregierung (2005), Stellungnahme der Bundesregierung zum Fünfzehnten Hauptgutachten der Monopolkommission 2002/2003, Bundestagsdrucksache 15/5819. (Response to the 15th Biennial Report of the Monopolies Commission).

Bundesverfassungsgericht (2011), Entscheidung vom 22. November 2011, 2 BvE 3/08.

Bundesverfassungsgericht (2014), Beschluss vom 14. Januar, 2014, 2 BvR 2728/13 u.a., (Decision to ask the European Court of Justice for an assessment of the compatibility of the ECB's OMT program with the Treaty) http://www.bverfg.de/entscheidungen/rs20140114_2bvr272813.html

Caprio, G., and Klingebiel, D. (1996), “Bank insolvencies: Cross-country experiences”, Policy Research Working Papier 1620, World Bank, Washington, D.C.

Caprio, G., and Klingebiel, D. (1997), „Bank insolvency: Bad luck, bad policy, or bad banking?”, Paper written for the Annual World Bank Conference on Development Economics, April 25-26, 1996.

Coase, R. (1972), "Durability and Monopoly", Journal of Law and Economics, 15(1), 143-49.

Crockett, A. (2000), "Marrying the micro- and macro-prudential dimensions of financial stability”, BIS Review 76, 1-7.

Deutsche Bundesbank (2012), „Stellungnahme gegenüber dem Bundesverfassungsgericht zu den Verfahren mit den Az. 2 BvR 2728/13“, (Statement to the German Constitutional Court in the Proceedings concerning the ECB's OMT program).

Eichengreen, B.J. (1992), Golden fetters, Oxford University Press, Oxford, U.K.

Ferguson, T. and P. Temin (2004), "Comment on 'the German Twin Crises of 1931."

Journal of Economic History 64 (3), 872-876.

Goodhart, C.A.G.(1988), The evolution of central banks, MIT Press, Cambridge, MA.

Goodhart, C.A.G. (1998), “The Two Concepts of Money: Implications for the Analysis of Optimal Currency Areas.” European Journal of Political Economy 14: 407-432

Friedman, M., and Schwartz, A.J. (1963), A monetary history of the United States 1867 1960, Princeton University Press, Princeton, N.J. 
Grilli, V., Masciandaro, D., and Tabellini, G. (1991), “Institutions and policies”, Economic Policy 6 (13), 341-392.

Hartmann-Wendels, T., M.F. Hellwig, and Manfred Jäger-Ambrozewicz (2010), Die Arbeitsweise der Bankenaufsicht vor dem Hintergrund der Finanzkrise (Supervisory practices in Germany in the light of the Financial Crisis), Analysen: Forschungsberichte des Instituts der Deutschen Wirtschaft No. 63, Cologne 2010.

Hayek, F.A. (1977), The denationalization of money, Institute for Economic Affairs, London.

Hellwig, M.F. (1985), “What do we know about Currency Competition?”, Zeitschrift für Wirtschafts- und Sozialwissenschaften 105, 565-588.

Hellwig, M.F. (1993), “The Challenge of Monetary Theory”, European Economic Review 37, $215-242$.

Hellwig, M.F. (2007), “Switzerland and Euroland: European Monetary Union, monetary stability and financial stability”, in: The Swiss National Bank 1907 - 2007,, Verlag Neue Zürcher Zeitung, Zürich, 741-780.

Hellwig, M.F. (2011), “Quo Vadis Euroland? European Monetary Union Between Crisis and Reform”, in: F. Allen, E. Carletti, G. Corsetti (eds.), Life in the Eurozone: With or Without Sovereign Default?, FIC Press, Wharton Financial Institutions Center, Philadelphia, 59-76.

Hellwig, M.F. (2013), „Stellungnahme zur Anhörung des Haushaltsausschusses der Bürgerschaft der Freien und Hansestadt Hamburg über die Wiedererhöhung der Ländergarantie für HSH Nordbank am 30. April 2013“ (Statement before the Budget Committee of the Parliament of the City of Hamburg in a Hearing Concerning the Increase of State Guarantees for HSH Nordbank), Max Planck Institute for Research on Collective Goods, Bonn, http://www.coll.mpg.de/sites/www.coll.mpg.de/files/text/Anhoerung_HSH_Nordbank.pdf

Hellwig, M.F. (2014 a), "Yes, Virginia, There Is a Banking Union! But it May Not Make Your Wishes Come True”, Paper presented at the $42^{\text {nd }} 42$ nd Economics Conference of the Austrian National Bank, May 12 - 13, 2014, mimeo, Max Planck Institute for Research on Collective Goods, Bonn..

Hellwig, M.F., (2014b), "Systemic Risk and Macro-Prudential Policy”, Paper presented at the High-Level Seminar on Macro-Prudential Policy, Nederlandse Bank, June 10, 2014, mimeo, Max Planck Institute for Research on Collective Goods, Bonn.

Hoshi, T., and Kashyap, K. (2004), “Japan’s financial crisis and economic stagnation”, Journal of Economic Perspectives 18 (Winter), 3-2 6. 
Hoshi, T., and Kashyap, K. (2010), “Why did Japan stop growing?”, NBER woring paper, National Bureau of Economic Research, Cambridge, MA.

Howitt, P. (2012), "What have central bankers learned from modern macroeconomic theory?”, Journal of Macroeconomics 34, 11-22.

International Monetary Fund (2008), Containing Systemic Risks and Restoring Financial Soundness: Global Financial Stability Report, April. http://www.imf.org/External/Pubs/FT/GFSR/2008/01/index.htm.

Monopolkommission (2004), Wettbewerbspolitik im Schatten ,Nationaler Champions': Fünfzehntes Hauptgutachten 2002/2003 (Competition policy in the shadow of 'national champions': Fifteenth Biennial Report), Bunestagsdrucksache 15/3610, also NomosVerlag, Baden-Baden 2005.

Sapir, A., Hellwig, M.F., and Pagano, M. (2012), A contribution from the Chair and ViceChairs of the Advisory Scientific Committee to the discussion on the European Commission's banking union proposals, Report No. 2 of the Advisory Scientific Committee of the European Systemic Risk Board.

Sargent and Wallace (1981), "Some unpleasant monetaist arithmetic”, Federal Reserve Bank of Minneapolis Quarterly Review 5 (3), 1-17.

Schnabel, I. (2004). “The German Twin Crisis of 1931” Journal of Economic History 64: 822-871.

Schnabel, I. (2009). “The Role of Liquidity and Implicit Guarantees in the German Twin Crisis of 1931.” Journal of International Money and Finance 28: 1-25.

Sinn, H.-W. (2012), Die Target-Falle, Hanser-Verlag, München.

Sinn, H.-W. (2013), „Verantwortung der Staaten und Notenbanken in der Eurokrise:

Gutachten im Auftrag des Bundesverfassungsgerichts, Zweiter Senat

Verfassungsbeschwerden 2 BvR 1390/12, 2 BvR 1439/12 und 2 BvR 1824/12

Organstreitverfahren 2 BvE 6/12” (Responsibilities of States and Central Banks in the Euro Crisis: Statement before the German Constitutional Court in the Proceedings concerning the ECB’s OMT program), mimeo, CES-ifo Group, Munich, June 2013.

Svensson, L. (1999), "Inflation targeting as a monetary policy rule”, Journal of Monetary Economics 43 (3), 607-654.

Tanzi, V. (1969), The Individual Income Tax and Economic Growth. Johns Hopkins University Press, Baltimore. 
Thornton, Daniel. 1984. "Monetizing the Debt.” Federal Reserve Bank of St. Louis Review (December): 30-43.

Tobin, J. (1963), “An essay on the principles of debt management”, Commission on Money and Credit (ed.), Fiscal and Debt Management Policies, Prentice Hall, Englewood Cliffs, N.J.

White, W. (2007), „Is Price Stability Enough?“, in: The Swiss National Bank 1907 - 2007,, Verlag Neue Zürcher Zeitung, Zürich,647 - 677.

Woodford, M. (2003), Interest and prices: Foundations of a theory of monetary policy, Princeton University Press, Princeton, N.J.

Woodward, B. (2000), Maestro: Greenspan's Fed and the American Boom, Simon \& Schuster, New York. 